„. . a pártirányltás vizsgálatára alkalmatlanok a normativ - dokumentumelemz 6 módszerek. A helyi közösségvizsgálatok számára egyik, különösen nehéznek ígérkezó feladat a pártirányitást jobban megközelító metodika kidolgozása." (52. oldal). Kétségtelen a szerepe a községi politika formálásában, de ezt nagyon nehéz az Irásos dokumentumok alapján tettenérni. A Hazafias Népfront helyi bizottságáról megrajzolt kép alapján egy olyan szervezet múködésérbl szerzünk benyomásokat, amely nem igazán tényezo a helyi politika alakitásában - annak ellenére, hogy e szervezet érintkezik a lakosság legszélesebb rétegeivel.

A helyi gazdálkodó szervek múködéséröl adott rövid összegzés olvastán egyre határozottabban fogalmazódott meg bennem a kérdés: hol van itt a helyi hatalom? Tény az, hogy a térségben müködó szinte valamennyi gazdálkodó szerv vezetóje vagy vezetóllású dolgozója tagja valamilyen, a községet érintb döntésthozó szerunek. Azonban igazán egyik gazdálkodó szervnek sincs szerves, mély hatása a község fejlరdésére, egymás között sem alakult ki tartós együttmüködés. Jogosan merül fel ismét a kérdés: beszélhetünke Pécsváradon he- lyi hatalom létezésérol? A pécsváradi államipolitikai intézményrendszer egyes elemeinek vizsgálata is sugallta a választ, mely kategórikus nem. Ahogyan Gombár Csaba értelmezi a helyi hatalom lényegét - s a szerzơ ebben az értelemben használja a fogalmat -, az a fajta hatalom semmiképpen sem létezik Pécsváradon. Az eddig elmondottakon túl egr konkrét döntési szituáció körül kialakult huzavonák is a helyi hatalom nemlétét igazolják - a nagy. község összevont rendezési tervéröl van szó, (70-75. oldal).

A szerző korántsem tekinti témáját lezárt nak. A felsorolt szempontok alapján a vizsgálat, illetve az elemzések folytatása még hosszú évekre való munkát ad. Ami talán „szépséghibája" a dolgozatnak: a szerzó elószeretettel használ hosszú, többszörösen bóvitett körmondatokat, holott a tanuimány tudományos értékét sem rontaná a tömörebb fogalmazás. A továbbgondolásra ösztönzó tanulmánykö. tetet gazdag irodalomjegyzék $s$ a vizsgált idరszak Pécsváradának legfontosabb ismérveit tartalmazó nyolc táblázat zárja.

TÓTH ÉVA

\title{
SOZIAL- UND VIRTSCHAFTSGEOGRAPHIE 2. STUDIENAUSGABE. EINFÜHRUNG IN DIE SOZIALGEOGRAPHIE, VERKEHRSGEOGRAPHIE, FREIZEITSTANDORTE UND FREIZEITVERHALTEN, RAUMORDNUNG UND LANDESENTWICKLUNG.
}

\begin{abstract}
(Társadalom- és gazdaságföldrajz 2. kötet. Bevezetés a szociálgeográfiába, a szabadidő-telephelyek és a şabadidő eltöltésével kapcsolatos magatartás földrajzába, a területrendezésbe és területfejlesztésbe. - HARMS Handbuch der Geographie. Paul List Verlag München, 1982. 350 p.).
\end{abstract}

Az NSZK-ban több kiadó is foglalkozik födlrajzi és térgazdasági tárgyú kézikönyv-szériák megjelentetésével. A müncheni kiadónak a "társadalom- és gazdaságföldrajz" hazánkban legmostohábban kezelt részei számára szerkesztett 2. kötete lényegében a harmadik és negyedik szektor földrajzát, valamint a területfejlesztés általános kérdéseit tartalmazza, igy joggal válthat ki érdeklödést Magyarországon.
Az elsర részt a Magyarországon elöszö! LETTRICH E. által röviden bemutatott, majd az utóbbi években lényegében BERÉNYI I. és osztálya által müvelt, de magyar nyelvü kézikönyvben még meg nem jelentetett szociálgeográfiát a müncheni $K$. RUPPERT-féle iskolához tartozó J. MAIER írta „Bevezetés a szociálgeográfiába" címen és mindjárt az elsó alfejezetben meg is magyarázza a ,bevezetés" 
céliát, sót a földrajz mibenlétét. (Hogy erre még ilyen speciális témájú múben sem felesleges kitérni, azt a hagyományos tudálékos indoklás helyett szarkasztikus módon Sain. Exupéry „Kis herceg”-éból vett, a laikus közfelfogást jól tükrözó idézettel szemlélteti: „Mi hát a geográfus, Ő egy tudós, aki tudja, hol vannak a tengerek, az áramlások, a városok, a hegyek és a sivatagok. Hiszen ez nagyon érdekes, ... végre egy igazi foglalkozás!") E studium feladatának azt tartja, hogy mind alkalmazott földrajzi és területtervezési, mind funkcionális, strukturális, tudománytörténeti-metodológiaik vagy történelmi-genetikus dimenziósíkból közelítse meg a témát, mivel nemcsak abból a célból írta opusát, hogy a hallgatók tanuljanak belóle, hanem azért is, hogy vitaalapot teremtsen a szakmabelieknek, de az érdeklơdớknek is érdekes, igényes ismereteket nyújtson.

Nagyiából egyenlơ terjedelmet szentel a szerzó „A szociálgeográfiai kutatás szemléletmódja"-nak és a „Szociálgeográfiai kutatás tematikus súlypontja" c. két nagy kérdéscsoportnak. Az elsót a tudományág fejlódéstörténetével kezdi, bemutatja az 1960-as évek még kiforratlan koncepcióitól a "tevékenységtérségi" tanulmányok készitéséig megtett utat, az újkeletú vitáknak a diszciplina tematikájának kiszélesítésére és a szemléletére gyakorolt kedvezơ hatását. Ide tartozik a tevékenységtérségi szemléletnek, valamint az "idó-földrajz" és az észleléspszichológiai megfontolásoknak a téralakitás munkájában - a döntésorientált becslésszempontok alkalmazásával, a politikai-gazdasági döntéshozóknak a jóléti gazdasági meggondolások figyelembe vételével - történơ felhasználása. A második kérdéscsoportban a térbeli foylamatok innovációit és diffúzióját, valamint a regionális egyenetlenségek beépítése igényének figyelembevételével kialakított területrendezés-politikai koncepciót tekinti a legfontosabbnak.

A recenzens érdeklödésére különösen számot tartó K. SCHLIEPHAKE által írt közlekedésfö/drajzi rész háromszor terjedelmesebb a szociálgeográfiainál és szerkezetében alapvetóen különbözik a hazai közlekedésföldrajzi szakkönyvek tematikus felépítésétól. Az elsó fejezet (,A közlekedés mint térbeli jelenség") a közlekedésföldrajznak a geográfián belül elfoglalt helyével, létezési alapfunkcióival, tudománytörténetével és a mai koncepciójával foglalkozik. Nagy súlyt helyez a közlekedés közvetlen és közvetett területi hatékonyságának kérdésére, a természeti viszonyok által nagymértékben befolyásolt térbeli közlekedési folyamatoknak közlekedési területi rendszerré való leképzódésére. Végigvezeti az olvasót a közlekedésföldrajz szemléletmódjának történeti vátlozásain, a közlekedésnek a településekkel való kapcsolatát elótérbe helyezó legrégebbi felfogástól a morfogenetikus és funkcionális irányzatokig és a mai közlekedésföldrajz viszonyát a reá nem egyszer egyaránt igényt tartó többi földrajzi részdiszciplinához, továbbá a komplex közlekedéstudományhoz, a gazda. ságtanhoz és több társadalomtudományhoz.

A közlekedés iránti kereslet jelenségeket tárgyaló második fejezet elemzi a közlekedési szükségletek tényezóit, kiváltó okait, így az iparosodás és munkamegosztás révén a lakosság mobilizációjának - a rendszeres ingázást is kiváltó - fokozódását, az anyagszállítási igények megtöbbszörözódését, a hírek, informá. ciók továbbítása iránti igények mindennaposssá és széleskörưvé válását.

A közlekedés kínálati oldalát tárgyaló fejezet bemutatja a közlekedési pályák, eszközök, formák és rendszerek szerinti strukturáltságát. A különbözơ közlekedési pályáknál nem annyira az ágazati munkamegosztásban elfoglalt funkciójukra helyezi a hangsúlyt, hanem inkább történeti fejlödésükre, sok adattal - és fóként németországi példákkal - szemléltetve. Amikor azonban a bizonyos absztrakcióval megteremtett fejlơdési modellekrơl szól, gyakrabban nyúl angolszász területekröl származó paradigmák után. (PI. a kikötơk továbbfejlơdési fázisait tartalmazó BIRD-féle 6 fokozatú "Anyport-modell".) A közlekedési hálózatok alaki, formai típusaira és ezeknek gazdasági következménveire egészen röviden, - de a gráf elméletet sem nélkülözve - tér ki. $A z$ egyes közlekedési eszközök elơnyeit és hátrányait szembeállító, a recenzensnek is sok ujjat hozó értékelés zárja a fejezetet.

A közlekedés és természet közötti - régebbi szerzóknél túlhangsúlyozott - kölcsönhatás mindkét irányának rövid értékelése után a közlekedés és a gazdasági tér közötti sokrétü kapcsolatokat a részletes - és kutatók számára a korábbi fejezetekhez képest sokkal több szakmai értéket hordozó - fejezetben tárgyalja. A közlekedés általi tértagolás néhány hayyományos - fóként a vonzáskörzetekkel, zónák- 
kal összefüggó - területi formái mellett olyan területi egységekról is szó esik, amelyek mesterkélt, hipotetikus fogalmaknak látszanak (pl. a „,közlekedési megye"). A közlekedést kényszerpontjai természeti, gazdasági és politikai tényezők által kikényszeritő helyeknek (Zwangspunkte) és a természeti tényezök közlekedéssel szembeni ellenállásának rövid ismertetése közvetlenül átvezet a közlekedés társadalmi szintú költségeihez és hasznához, végigvezetve a közlekedési költségeknek a különféle telephelyeleméletekben elfoglait szerepét.

A közlekedési áramlásokkal foglalkozó fejezet sok minden között megismertet a gravitációs modellek, a településhálózati centralitás és áramlás összefüggésével. A közlekedés és területfejlesztés egymásrahatásáról írt fejezetben a magyar olvasó alig ismert jelenségekről (pl. az olajvezetékek és kikötök térbeli viszo. nyáról) kap részletes információt. Egyik legjobban kidolgozott és összefoglalt alfejezete a közlekedés és települések viszonyát fejtegetó, ahol a közlekedésföldrajz hagyományos problémájáról, az elérhetóségi vizsgálatokról is szó van, de modernebb metodikai megoldásokkal kiegészítve. A szerzó a városi közlekedés problémáit is bevonta a közlekedésföldrajzba, e gondolattal még meg kell berátkozni, mivel a téma természete és nagyságrendje miatt inkább közlekedésüzemi, üzemszervezési feladatnak, semmint geográfus által eredménynyel kutatható témának érezzük.

A közlekedésáramlási adatok felvételével és elemzésével foglalkozó közlekedésanalizis, a közlekedéstervezés, a közlekedéspolitika, a közlekedés és környezetvédelem egymásra hatásának témája képezi az utolsó elotti fejezetet, míg a zárófejezet a közlekedés várható jövőjéról ad elképzeléseket.

Miután hazánk nemzeti jövedelméból mind nagyobb arányban részesedik az idegenforgaIom, haszonnal forgathatják a könyv harmadik (J. MAIER által írt) részének lapjait a szakmabeliek, amely a jelenségek megközelitésében korszerü szociálgeográfiai szemléletével messze túlhaladja a magyar kutatókét. A ,szabadido" eltöltés helyeinek és résztvevoói magatartásának földrajza" jóval komplexebb téma a hagyományosnál laz idegenforgalom területi megoszlásának, szerkezetének ábrázolásánál és magyarázatánál), mert a kultúrtájjal való kölcsönhatás, továbbá az embereknek a szabadidő eltöl- tésével kapcsolatos - társadalmi, anyagi helyzetük, hagyományaik, mentalitásuk stb. - motivációja vizsgálatát is felvállalják múveloi. A részletesebb tartalom ismertetés helyett (terjedelmi korlátok!) csak néhány témát emelünk ki: a szabadidó funkció történeti fejlódése, viszgálati nézópontjaanak, metodikájának fejlódése, az idegenforgalmi kereslet és kínálat struktúrái, a második otthon szerepének, elterjedettségének, a tulajdonosok kilétének területi sajátosságai (a szocialista országokból csak a magyarországi helyzetet tartalmazza), a város mint szabadidótérség, a szabadidð tevékenység prognosztizálásának, a területi tervezésben való megjelenitésének szükségessége ès lehetơsége, többek között az ökológiai terhelés gondjai miatt.

A könyv harmadik, a területrendezéssel és -fejlesztéssel foglalkozó része (J. HAGEL munkája) azért hézagpótló sokunk számára, mert tömör és arányos összefoglalást ad - számos jellemzó adattal szemléltetve - a kapitalista országok ilyen irányú (számunkra többnyire csak esetlegesen ismert) közös és eltéró vonásairól, cél- és eszközrendszeréról. Meglepóen régi történeti időktól kapunk áttekintést e tevékenység fejlódéséröl, különválasztva a várostervezést a regionális és területi tervezéstöl, sorba véve a különféle eszményképeket, koncepciókat, a tervezés nagyságrendi metszeteit és területi egységeit a természeti adottságokra, környezetre, társadalmi-gazdasági viszonyokra, infrastruktúrára is kiterjedó területi elemzés és prognózis készités módszereit, a tervmegvalósítások ellenőrzését, a területfejlesztés-politika eszközeit.

Több szerzơs a könyv, de egyik része sem jellemzó, hogy szerź́jének a koncepcioja dominálna a mondanivalóban. Tisz tele tben tartva a tankönyv-kézikönyv müfajjal szemben az egyetemes ismeretek iránti elvárást, a szerzók rendkívül széles körü - de mintegy kétharmadában német nyelvü - pontosan hivatkozott szakirodalomból írták meg részeiket, így saját felfogásuk jobbára a szerkezetadásban és kevésbé az egy-egy problémával kapcsolatos eltéró vélemények és megközelítések kezelési módjában, interpretálásában jutott kifejezésre, - a saját vélemény túlhangsúlyozásától pedig még az elvi kérdéseknél is óvakodtak.

Remekül ötvözi a könyv a makroszintú (országonként, nagyrégiónként tagolt) । és a mikroszintü (kiskörzeti, települési, település- 
részenkénti) ismereteket. Nagyban megkönnyíti az írásos információ strutkúrájának áttekintését, a vezérszavak kiemelését a sokféle betütípus alkalmazása és a fóbb alkérdések pár szavas megjelenitése a margón. Erre azért van igazán szükség, mert hallatlanul széles tematikus spektrumú anyagot ölel fel a kötet, igen fegyelmezett tömörséggel, igy nem térhet $\mathrm{ki}$ a részletekre, hanem az altémák leglényegesebb elvi jelentơségü. a metodika megválasztásában is orientáló összefüggéseinek, illetve a szemléletünk alakitására is képes struktúrájának közreadására szorítkozik.

Ábrái nemcsak múfajukban, de a szemléltetés célját illetøen is hallatlanul sokfélék és a táblázatok adataihoz hasonlóan feltünően friss információkat tartalmaznak. Közülük különö- sen a soktényezós térjelenségek bonyolult belsơ összefüggéseinek és külsơ kapcsolatainak áttekintését megkönnyító, egyértelmüvé tevó modell és rendszerkszerkezet ábrák, valàmint a szines térképek, metszetek (pl. több tengeri kikötŏról, az Északi-tenger szénhidro. gén mezóinek a partokig épitett csర̋vezetékhálózatáról, Schleswig-Holstein idegenforgalmi objektumairól, a Rajna-Majna-Duna csatornáról) figyelemre méltóak, többségük nemcsak szakmai csemege, de igazi látványélmény is.

A könyvet tankönyv és kézikönyv íróinkon, kiadóink szerkesztóin kívül a területi kérdésekkel foglalkozó valamennyi kollégánknak ajánljuk.

\title{
GURZÓ IMRE: KÖRKÉP A HAZAI CUKOR-, NÖVÉNYOLAJ- ÉS DOHÁNYVERTIKUMRÓL
}

\author{
Gondolatok három könyv kapcsán
}

Jó néhány évvel ezelótt széles körben ter jedt el az a nézet, hogy az agrárgazdaság harmó nikus fejløddéséhez mind a tervezésben, mind az irányításban, mind pedig a gyakorlati életben komplex, termelésifolyamat-orientált szemléletmódra és problémakezelésre van szükség. Ez azt jelenti, hogy a széles értelemben vett élelmiszergazdaságot különböző, sok szállal egymáshoz kapcsolódó vertikumok (gabona, hús, zölség-gyümölcs, cukor, növényolaj stb.) egységes rendszereként fogjuk fel. E felépités tudományos megalapozása hazánkban lényegében már megtörtént. Több szerzó (pl. Benet l., Bethlendi L., Csizmadia E., Fekete F., Márton J., Németi L., Udovecz G., Vági F. stb.) behatóan foglalkozott a problémával, illetve annak egyegy részterületével. Ennek ellenére a hazai gyakorlat még mindig adós az élelmiszergazdaság végtermék-szemléletủ megközelltésével: a termelés különbözŏ fázisaiban múködర̆ megzŏgazdasági üzemek, a szállítással, feldolgozással, értékesítéssel foglalkozó vállalatok sokszor nem közös érdekeltség keretében fejtik ki tevékenységüket. Még $\mathrm{ma}$ is megfigyelhetók érdekellentétek, monopolisztikus hely- zetekból adódó elónyök-hátrányok, adminiszt ratív döntésból eredŏ kényszerek stb. Ezek hátráltatják egyegy vertikum fejlódését, sok esetben abszolut módon is visszavetik azt, végs 8 soron a társadalmi termelés hatékonyságát rontják. Az ilyen jellegú problémák feltárása, a precíz helyzetelemzés, a kezelés módjának lehetséges alternatívái stb. mind-mind olyan kérdések, amelyek felé joggal fordult a szakemberek figyelme. Örvendetes tény, hogy az egyre gyarapodó magyar közgazdasági szakirodalomban megszaporodott azon könyvek száma, amelyek egyegy hazai élelmiszergazdasági vertikum fejlödését, jelenlegi állapotát és elórelépésének lehetséges (kivánatos?) útját nagy részletességgel rajzolják meg. llyen mú a Mezógazdasági Kiadó gondozásában Bélteky Béla tollából megjelent .A cukorvertikum gazdaságosság" (Bp., 1985. p. 149.) a Barta Attiláné által írott „A növényolajvertikum gazdaságossága" (Bp., 1986. p. 177.) és a Borsos János szerzóségével fémjelzett "Integráció és termelésfejlesztés a dohánygazdaságban" (Bp., 1986. p. 231.) címú könyv. 